\title{
NEGATIVE FACTORS AFFECTING THE EFFICIENCY OF RESTRUCTURATION OF PUBLIC HOSPITALS
}

\author{
Karolina WIELICKA-GAŃCZARCZYK \\ The Silesian University of Technology, Gliwice; Karolina.Wielicka-Ganczarczyk@polsl.pl, \\ ORCID: 0000-0001-5475-6661
}

\begin{abstract}
Purpose: To diagnose causes of unsatisfactory (failure factors) of restructuring operations undertaken in public hospitals located in the Silesian Province (Śląskie Voivodeship). A level of achievement of an individual objective set for restructuring operation was a measure of their effectiveness.
\end{abstract}

Design/methodology/approach: The present research study was conducted in three stages and preceded by pilotage. In the first stage, the process of restructuration as perceived from public hospitals was analysed, in the second stage - from the point of view of their establishing entities. Two survey questionnaires were used to accomplish these stages. The research studies were conducted among the management staff of 17 public hospitals and among 14 establishing entity representatives. The third step was aimed at assessing and sorting all the identified failure factors. The group expert assessment method was applied for its implementation by 20 people. Findings: The most common objective of public hospital restructuration was to improve the quality of provided services and then to reduce debts. The average degree of achievement of the first objective amounted to $75.2 \%$, while the second $-67.7 \%$. The research studies led to the identification of 30 factors which have a significant negative influence on restructuration; among them 'adoption of improper assumptions on the restructuring plan in relation to financial forecasting' was considered the most important.

Research limitations/implications: The research studies were conducted in public hospitals located in the Silesian Province (Śląskie Voivodeship) and which operated as independent public health-care units.

Practical implications: In order to conduct restructuring operations, public hospitals and their establishing entities should apply project management methodologies, under which they will plan and implement their restructuring operations.

Originality/value: Studies have shown the effectiveness of restructuring hospitals located in Silesia and identified the factors that have a negative impact on hospital restructuring.

Keywords: healthcare system, public hospital, restructuring, effectiveness, Poland.

Category of the paper: research paper. 


\section{Introduction}

The health-care sector is characterised by its high volatility (Klich, 2013, p. 15); thus, hospitals which operate within this sector are at risk of having to continuously adapt to forthcoming changes. One of today's requirements for running public hospitals is to systematically increase their effectiveness by consistently reducing costs and eliminating all waste, while at the same time focussing on new technologies and their implementation (Kautsch, Lewandowski, 2013, p. 5). Thus, in terms of such undertaken actions, their effectiveness, which also covers their efficiency (Saryusz-Wolska, Wronka, 2013, p. 256, 258), has become a relevant problem to tackle.

The notion of effectiveness is not identical to the notion of efficiency (Pszczołowski, 1978, p. 60). Effectiveness refers to economy and is expressed on the basis of financial means, such as a relation between expenditures incurred and any results obtained (Pyszka, 2015, p. 15). In the scope of health-care, effectiveness may be extended through clinical and practical aspects (Michalski, 2013, p. 207; Hass-Symotiuk, 2011, p. 80). Nowadays, there has been a prevailing opinion expressed in literature on the subject of effectiveness consisting of performance and efficiency (Furtak-Niczyporuk, Drop, 2013, p. 54). Performance refers to a manner of operation (Kowal, 2013, p. 14) and occurs where the workload can be perceived and not its output. As a result, this can be assessed in the course of operations by means of such measures as, for example, dexterity or proficiency (Filipek, 2016, p. 41). In turn, efficiency then refers to actions and their results intended to be achieved under any set objective (Skrzypek, 2012, p. 315). Thus, operations are considered effective when they were planned and accomplished (Jaruzelski, 2009, p. 8), and management effectiveness will mean the ability to point the specific objectives understood as right-to-be-accomplished actions (Penc, 2003, p. 16). The degree of achievement of set objectives is a measure of efficiency of such operations (Kotarbiński, 1982, p. 106), and therefore it is possible to assess only such actions when their realisation was completed and which were aimed at achieving a particular objective (Sułkowski, Wolniak, 2013, p. 65).

Given the fact that the performance and effectiveness of the Polish health-care system and its operational entities remains low (Klich, 2013, p. 261), it is important to become acquainted with the factors which affect the efficiency of hospital processes (including restructuration processes). 


\section{Success and failure factors}

Factors which affect an individual organisation and its operation may be considered in two aspects: positive or negative. Factors in the first group are called "key success factors" and mostly aim to improve the competitiveness or profitability of business units (ZakrzewskaBielawska, 2007, pp. 276-277). Such factors are identified for each and every sector separately, since each of them has a different set of factors (Klonowska-Matynia, Stasiukiewicz, 2015, p. 69). Due to the fact that some factors affect an individual business unit more or less, it is not necessary to consider them all in depth (Guesses, Romanowska, 2007, p. 169). The Pareto principle, according to which only $20 \%$ of factors account for business success, may be applied for their analysis. A literature review on the subject shows that the application of key success factors from the commercial sector in strategic management in public organisations (as per new public management) is marginal (Austen, Kotas, 2016, p. 46).

There is no term which would be generally accepted and defined in literature to cover factors which have a negative impact on an organisation. They are referred to by researchers as: failure factors which determine causes of failing to achieve success (Ropęga, 2016, p. 502), setback factors or threat sources (Nieżurawski, Nieżurawska, p. 274), limiters, barriers (ZakrzewskaBielawska, 2004, p. 7) or risks (Pasieczny, 2013, p. 357). The last may, however, also be considered as an event with a positive impact.

Failure to fulfil success factors may turn into a failure of business, just as avoidance or weakening failure factors may contribute to its success. When the issue is considered from the point of view of factors which account for the efficiency or inefficiency of a specific process, such as restructuration, the following can be listed, among others:

- projected unsatisfactory efficiency (Nalepka, 1998, p. 40), i.e.:

- over-sized organisation,

- inadequate range of accomplished actions,

- limited independence of decision-making capabilities of managerial staff;

- conditions of an effective restructuring programme (Suszyński, 1999, p. 124), such as:

- setting measurable objectives based on prior diagnosis,

- resources (human and material) to be applied to perform individual tasks under their deadlines;

- obstacles in the course of restructuration identified on the basis of the research studies conducted in large enterprises in three sectors, i.e. light sector, energy sector and construction sector (Zakrzewska-Bielewska, 2004, p. 9), which include:

- "poor economic situation",

- "no stable government economic policy",

- unsecured financial means for undertaken actions,

- no adjustment of legislation to new requirements, 
- low level of acceptance of the restructuring process among staff,

- resistance of trade unions,

- no adequate management experience in the design and implementation of restructuration,

- no transparent business development strategy;

- principles of restructuration and its proceedings, taking into consideration human resources and processes (Dobska, Rogoziński, 2008, pp. 147-148), which include, among others:

- clearly defined purpose,

- full involvement of the management board in undertaken actions,

- planning a restructuring programme so that it answers the following questions: what, how, when and why;

- mistakes made in restructuring processes broken down into preparation and implementation stages of the restructuring programme (Mozalewski, 2010, p. 233), which include, among others:

- concentration of the planning team on one study/research,

- only managers appointed to join the planning team,

- taking unrealistic assumptions on future revenue,

- underestimation of costs.

Literature on the subject abundantly presents risks and their origins, i.e. key success factors for commercial enterprises in various industries. However, the public sector calls for further exploration, because there are scarce research studies on this subject, as evidenced by the works of M. Kotas (2014, p. 362) or M. Wronki (2013, p. 4).

\section{Characteristics of the research study}

The key purpose of the research study was to diagnose the unsatisfactory efficiency (failure factors) - together with its causes - of restructuring operations undertaken in public hospitals located in the Silesian Province (Śląskie Voivodeship). A level (degree) of completion of an individual objective planned for hospital restructuration subjectively assessed by the respondents (in \% from 0 to 100) was a measure of efficiency. The present research study was conducted in three stages and preceded by pilotage. In the first stage, the process of restructuration as perceived from the perspective of a public hospital was analysed, and in the second stage - from the point of view of its establishing entity. The third stage consisted in evaluating and arranging a list of failure factors selected from the first and second stages. The group expert assessment method and the object relative relevance method were applied for its completion. 


\subsection{Criteria for participation in the research study}

The research study covered public hospitals which successfully passed the two-stage selection process. In the first stage, some preliminary criteria were identified, according to which hospitals:

- provided medical treatment in the form of stationary and all-day hospital services,

- run their business in the form of independent public health-care units,

- did not run business on the basis of a public-legal partnership in the course of the research studies,

- were multi-field hospitals, with at least two units with different specialisations and none belonging to any external entity,

- were not scientific and didactic centres for medical schools, and thus they were not established by any State medical school or a State university conducting didactic or research activities in the field of medical sciences,

- where the Governor of the Silesian Voivodeship (Śląskie Province) or a local government unit was their registration authority, which excluded its registration by any ministerial bodies, such as the Ministry of the Interior.

On the grounds of the public Register of Health Care Operators, 36 public hospitals which fulfilled the above prerequisites were identified in the Silesian Province (Śląskie Voivodeship). On the basis of these qualified hospitals, the second group of participants, i.e. their owners, was set up - 17 altogether. A questionnaire survey was provided to people representing these public hospitals who were members of their management (managers) in the course of restructuring actions; then - on behalf of the establishing entities - it was provided to people participating in the restructuration of their hospitals and holding decision-making authority. Only feedback coming from hospitals and their establishing entities which underwent the restructuration process or were in the course of its implementation during the survey (the second stage of selection) was taken into consideration.

Experts who were members of management boards in public hospitals operating in the form of an independent public health-care unit (Pol. SPZOZ) and characterised by the continuity of their employment in this position for not less than 5 years were invited to assess the impact (degree) of failure factors on the restructuration of public hospitals (the third stage), determined on the grounds of the survey conducted in the first and second stages. Additional criteria were as follows: reaching a level of familiarity with the issue by an individual expert (at least 0.6) and reaching a level of argumentation source (at least 0.75 ).

\subsection{Participants}

Three groups of participants took part in the survey (depending on the stage of their completion). During the first stage, feedback was received from 22 public hospitals; however, due to failure to meet the second selection stage criterium, 17 of them only qualified for further 
surveying. 13.9 was the average number of units in these hospitals; 40 was the maximum, and 2 - the minimum. Hospitals with their stay facilities ranging from 400 to 600 beds accounted for $34.58 \%$ of the surveyed hospitals, those with more than 600 beds $-27.59 \%$, and less than 200 beds $-31.03 \%$, while other hospitals had 200 up to 400 beds. Most often the surveyed public hospitals had 4-person management boards (42.9\%), and in $28.6 \%$ of cases, they were composed of 1 person. For $14.3 \%$ - 2 persons, while others declared that their boards had 2 directors. The questionnaire was completed by 29 people meeting the criteria for participation. All the respondents had higher education, of whom $60 \%$ in the field of medicine, $25.7 \%$ - economics, $11.4 \%$ - management, and 5.8\% had technical higher education.

14 people representing their establishing entities who met the criteria for participation in the research study took part in the second stage. These people chiefly represented local selfgovernment units $(87.5 \%)$, while the remaining participants pointed out a variety of other hospital owners. $75 \%$ declared that the entity which they represent is the owner of one hospital, while others pointed out two hospitals. All the participants in the survey had higher education and held managerial positions.

20 experts who were members of management boards in public hospitals operating in the form of independent public health-care units (Pol. SPZOZ) were then invited to assess the factors in the third stage; however, due to failure to have 5 years of employment in this position and not meeting the required levels of familiarity with the issue and argumentation source, only 11 respondents were classified. $45.45 \%$ were female. Most of the experts were 47-57 years old (54.55\%), 36-46 years old (36.36\%) and 58+ years old $(9.09 \%)$. There were no assessors at the age of 35 and under. $54.55 \%$ of the experts had economic education, followed by medical and technicalat $27.27 \%$ each. The majority of the respondents $(54.55 \%)$ were employed as directors of independent public health-care units (Pol. SPZOZ), whilst others as economic/ financial directors $(36.36 \%)$ and medical directors $(9.09 \%)$.

\subsection{Applied research study methods}

A uestionnaire survey was used in the first two stages. The application of the questionnaire survey was aimed at gathering information on the planning and implementation of restructuring measures in hospitals and verification of their effects. Questions in the questionnaire referred to, in particular:

- role(s) taken by a hospital and its establishing entity during its restructuration,

- reasons for the launch of restructuring actions,

- objectives set for restructuration,

- project manager/project team and their competences,

- involvement of hospital staff and its establishing entity in restructuration,

- identification of restructuring areas and key actions taken within these area, 
- problems which occur during the planning and implementation of restructuring changes (negative factors which affect restructuration),

- statements made by public hospitals and establishing entities on commercialisation.

The questionnaire in the first stage consisted of 50 questions, 6 of which concerned basic data about the respondent, 18 referred to the area of planning, 15 - of implementation, and 11 - to the area which was conventionally called 'summary'. In the second stage, the questionnaire contained 44 questions, 3 of which concerned basic data about the respondent, 15 touched upon the area of planning and implementation, and 11 - the area called summary. The questionnaires included closed, open, semi-open, filtering and conditional questions.

In the third stage, the group expert assessment method was applied to assess negative factors which have a negative impact on restructuration, and the object relative relevance method was used to rank these factors. The selection of experts was conducted in two stages and was target oriented. People who participated in the restructuration of public hospitals and at that time held managerial positions, with 5 years of experience in this position, were invited to be surveyed in the first stage. The questionnaire presented to the experts consisted of three parts. The first covered a respondent's details, for which 4 questions were raised. The second part contained factors which negatively affect the restructuration of public hospitals, which were listed in alphabetical order. The experts were to rank each factor with an appropriate number of points (from 0 to 100), where 0 stands for no impact and 100 for very high impact on restructuring operations and their failure. The points given by one expert could be repeated. An expert might happen to be unable to determine the impact of a given factor on restructuring operations in the survey, and he/she then placed a dash (-) instead of giving points. The average value of assessment for the factor (not including the dash) was taken in the analysis for the evaluation of this expert. The third part of the questionnaire covered the expert's self-assessment questions and was in fact the second stage of their selection in the research study. It was assumed that an individual expert team which was appointed to solve a given issue should be characterised by a high level of competence $\left(\mathrm{K}_{\mathrm{k}}\right)$, which was calculated from the following formula:

$K_{k}=\frac{\mathrm{k}_{\mathrm{z}}+\mathrm{k}_{\mathrm{a}}}{2}$

where:

$K_{k}-$ coefficient of expert's competence,

$\mathrm{k}_{\mathrm{z}}$ - coefficient of expert's acquaintance/knowledge with a given issue, $\mathrm{k}_{\mathrm{a}}$ - coefficient of argumentation (argument factor).

Each of the calculated coefficients could have values from 0 to 1 , while $k_{z}$ and $k_{a}$ coefficients were independently evaluated by the expert. When $\mathrm{k}_{\mathrm{z}}$ was calculated, the expert chose a statement which best describes his/her acquaintance/knowledge on a given issue. Individual statements were assigned with values taken from the ten-scale scale, which - in order to calculate $K_{k}$ - were divided by ten. The expert's self-assessment scale on the degree of familiarity with a given issue is summarised in the table below. 
Table 1.

Expert's self-assessment $-k_{z}$

\begin{tabular}{|c|c|c|c|}
\hline Expert's self-assessment table - kz & \multicolumn{3}{|c|}{$\begin{array}{c}\text { Assessment - restructuration of an independent } \\
\text { public health-care unit (Pol. SPZOZ) }\end{array}$} \\
\hline The expert does not know the issue. & \multicolumn{3}{|c|}{0} \\
\hline The expert knows little about the issue. & 1 & 2 & 3 \\
\hline $\begin{array}{l}\text { The expert knows the issue fairly well, but he/she } \\
\text { does not participate in its practical solution. }\end{array}$ & 4 & 5 & 6 \\
\hline $\begin{array}{l}\text { The expert knows the issue well and takes part in its } \\
\text { practical solution. }\end{array}$ & 7 & 8 & 9 \\
\hline $\begin{array}{l}\text { The expert knows the issue very well - it belongs to } \\
\text { his/her narrow specialisation. }\end{array}$ & \multicolumn{3}{|c|}{10} \\
\hline
\end{tabular}

Source: own study research based on Męczyńska, A. (2007). Group expert assessment in management decision making. Scientific Works of the Silesian University of Technology, Organisation and Management, 40.

The $\mathrm{k}_{\mathrm{a}}$ coefficient covered the sources on which the expert assess the factors. The expert had to assess each source of argumentation he/she was provided by attributing it with one value taken from the three-tier scale, which specified the degree of influence of a given source on his/her assessment of factors. All the individual sources and degrees attributed to them were provided with point values, which were unknown to the experts. The sources of argumentation, along with their degrees of influence and assigned points, are shown in the figure below.

Table 2.

Impact of argumentation onto the expert's opinion $-k_{a}$

\begin{tabular}{|l|c|c|c|}
\hline \multicolumn{1}{|c|}{ Source of argumentation } & \multicolumn{3}{c|}{ Degree of argumentation } \\
\cline { 2 - 4 } & high & medium & low \\
\hline Expert's theoretical knowledge of problems & 0.3 & 0.2 & 0.1 \\
\hline Expert's own practical experience & 0.5 & 0.4 & 0.3 \\
\hline Knowledge based on other (foreign) experience & 0.1 & 0.1 & 0.07 \\
\hline Expert's intuition & 0.1 & 0.05 & 0.03 \\
\hline Coefficient of argumentation and its values & $\mathbf{1 . 0}$ & $\mathbf{0 . 7 5}$ & $\mathbf{0 . 5}$ \\
\hline
\end{tabular}

Source: own study research based on Męczyńska, A. (1999). Heuristic method - group expert assessment applied for the analysis of processes, products. IN R. Knosala (Ed.), Computer-integrated management. Warsaw: WNT Publishing House.

The value of the coefficient of argumentation was calculated by summing up all degrees of argumentation specified by an individual expert for each source to which points values were attributed. The following assumptions on the group expert assessment were adopted for the purpose of this research study:

- coefficients $\mathrm{k}_{\mathrm{z}}$ and $\mathrm{k}_{\mathrm{a}}$ have their values within $\langle 0.1\rangle$,

- coefficient $\mathrm{k}_{\mathrm{a}}$ is subject to decreasing from practical experience to theoretical knowledge on a given issue,

- coefficients of argumentation: $\mathrm{k}_{\mathrm{a}}=1, \mathrm{k}_{\mathrm{a}}=0.75, \mathrm{k}_{\mathrm{a}}=0.5$ correspond to individual degrees of impact of all sources of argumentation (high, medium, low),

- coefficient $K_{k}$ reaches a threshold value at $\geq 0.75$, which indicated that a given expert became qualified for the research study. 
Assessments made by each of the experts were sorted in a non-ascending order, and their ranks were then determined (if a given assessment was assigned once, then its rank was 1; when the same assessment was assigned to several factors, then its rank was equal to the arithmetic mean of ranks which they could get in case of getting different assessments). The experts' assessments were replaced by ranks and then sorted in a non-increasing order by the sum of ranks. The lower the sum of ranks, the higher the impact it has on the restructuration of hospitals.

\section{Findings}

The results of the research studies from the first two stages were summarised and shown together. The exceptions are three additional questions from the restructuring planning stage, as they related to the hospitals only and the separately presented results on the effectiveness of restructuration obtained from the hospitals and their establishing entities.

\subsection{Planning and implementation of restructuring operations}

Hospital recovery was the key reason for making a decision to start restructuring operations (as indicated by $86.2 \%$ of the managers and by $85.7 \%$ of the establishing entity representatives). All the undertaken restructuring operations did not affect their lack of indebtedness. At the time of running the research study, $86.2 \%$ of the hospital representatives stated that their hospital was still indebted. In the second group, $85.7 \%$ of the respondents pointed out to the indebtedness of their hospitals. A low contract value with the National Health Fund - NHF (Pol. NFZ, Narodowy Fundusz Zdrowia) was most often pointed to among the reasons for such indebtedness ( $67.2 \%$ of the hospitals and $83.3 \%$ of the establishing entities). Other reasons specified by the hospitals were as follows: financial losses incurred in previous years, no payment for overwork, maintenance of cost-intensive infrastructure, duplication of singlespecialisation units. As declared by the establishing entities, the following factors contributed to their hospital indebtedness: no payment made by the NHF for their services (including lifesaving or unlimited services), statutory salary increases in the hospital sector and too high share of remuneration costs in their hospital revenues.

According to the managers, their hospital took the following roles in restructuration: an implementing role $(93.1 \%)$, organisational $(82.8 \%)$ and initiative $(79.3 \%)$; while the establishing entity - supervisory (100\%), controlling (41.4\% \%) and planning $(37.9 \%)$. According to the establishing entity representatives, the hospital took the following role in restructuring: an initiating role (78.6\%), then supervisory role (71.4\%) and control role $(64.3 \%)$; while the hospital - implementting (85.7\%), initiating (50\%) and organisational (42.9\%). 
In the opinion of the managers, most often it was their hospital (96.6\%) which applied to undertake restructuring operations, while in the second group, $78.6 \%$ of the respondents pointed that it was the establishing entity. Both groups of the respondents stated that it was the hospital which was responsible for the implementation of restructuring operations (as indicated by $82.8 \%$ of the managers and $92.9 \%$ of the establishing entity representatives). $51.8 \%$ of people from the hospitals and $42.9 \%$ from the establishing entities stated that the person who was responsible for the implementation of restructuring operations participated in extra courses provided for this purpose. According to the hospital respondents, such trainings focused on financial control, risk management, modern hospital management and cost/revenue optimisation (20\%), while the establishing entity respondents did not provide answers to the question.

In the next question, the respondents were asked to declare which unit was accountable for conducting or defining project management activities, if such were conducted (Tab. 3 ).

Table 3.

Entity accountable for actions preceding implementation

\begin{tabular}{|l|c|c|c|c|}
\hline \multirow{2}{*}{\multicolumn{1}{c|}{ Defined, conducted }} & \multirow{2}{*}{$\begin{array}{c}\text { Share [\%] } \\
\text { hospital/entity }\end{array}$} & \begin{tabular}{c} 
Entity responsible for the task \\
\cline { 3 - 5 }
\end{tabular} & & \multicolumn{3}{|c|}{ Share [\%] hospital/entity } \\
\cline { 3 - 5 } & & $4.8 / 57.1$ & $95.2 / 71.4$ & $4.8 / 14.3$ \\
\hline pre-implementation analysis & $72.4 / 50.0$ & $0.0 / 100$ & $100 / 100$ & $0.0 / 0.0$ \\
\hline staff meetings & $34.5 / 14.3$ & $19.2 / 75.0$ & $88.5 / 50.0$ & $3.8 / 12.5$ \\
\hline actions to be performed & $89.7 / 57.1$ & $13.0 / 0.0$ & $100 / 100$ & $0.0 / 0.0$ \\
\hline resources required to perform actions & $79.3 / 28.6$ & $52.6 / 100$ & $84.2 / 30.0$ & $0.0 / 0.0$ \\
\hline project budget & $65.5 / 71.4$ & $26.3 / 100$ & $78.9 / 0.0$ & $5.3 / 0.0$ \\
\hline project risk & $65.5 / 14.3$ & $35.7 / 71.4$ & $100 / 42.9$ & $0.0 / 28.6$ \\
\hline project stakeholders & $48.3 / 50$ & & & consultancy \\
\hline
\end{tabular}

Source: own research based on questionnaire results.

According to the managers, the hospital was accountable for planning a set of activities to be conducted, identifying resources required to conduct such planned actions and making pre-implementation analysis. The establishing entity was primarily accountable for planning the budget of restructuring activities.

A project team was appointed for the planning and implementation of restructuring operations (69\% respondents from the hospital and $64.3 \%$ from the establishing entity). In the first group of respondents, $62.1 \%$ considered that it was the hospital that decided on its composition, while in the second group, $50 \%$ pointed to the hospital. According to the hospital representatives, the project team consisted of: top managers (100\%), administrative managers (70\%), ward managers (50\%), other administrative staff (40\%). Top managers (as indicated by $40 \%$ ) said that their project team members took part in extra trainings; most often they covered the following areas: hospital management, change, finance, quality management $(33.3 \%)$. According to the establishing entity representatives, their project team consisted of top managers (as indicated by 100\%), administration managers (37.5), other administrative and technical staff (25\%). 
During the planning of restructuring activities, the top managers identified 17 problematic areas, among which legal framework (as indicated by 24\%) was indicated most often. This problem occurred due to frequent changes of legal regulations and excessive length of procedures $(20 \%)$, which, as a result, led to: modifications made to plans $(28 \%)$, extra staff meetings aimed at convincing them to make changes (24\%), extended duration of restructuring activities (24\%). The respondents from the establishing entity identified 6 problematic areas, among which dissatisfaction of trade unions and people employed with planned changes (45.5\%) was indicated most often. This problem occurred due to fears of job loss and changes at work (professional position) (45.5\%), which led to: rising costs of restructuring operations, protests, strikes, prolonged restructuration resulted from lengthy mediation, consultation and reaching an agreement (27.3\%).

According to the top managers, restructuring operations were conducted in 8 areas, among them the respondents most often pointed to the following areas: employment and organisation (75.9\% each), followed by technical area and debt structure (72.4\%), services (69\%). A reduction in the number of people employed was the most common action undertaken in the area of employment. Within the organisational area, focus was on making changes in the range of subordination and outsourcing or elimination of non-medical services $(23.53 \%$ each). In the technical area, the focus was on purchasing new diagnostic equipment $(63.16 \%)$, in the debt structure - on reducing hospital operational costs $(31.25 \%)$, and in the range of services - on providing new health services $(50 \%)$. According to the respondents from the establishing entity, restructuration touched upon 8 areas, among them the following areas were most often pointed out: organisation $(92.9 \%)$, followed by services and employment $(78.6 \%$ each), management and structure (64.3\% each). Within the organisational area, a merger of administrative cells was the most common action (46.2\%), while in the area of employment, focus was on its rationalisation $(90.9 \%)$, and in the area of services - on their extension $(63.6 \%)$. In the area of management, actions were aimed at eliminating competition between and among hospitals with the same owner $(33.3 \%)$, while under the debt structure, focus was on its reduction $(88.9 \%)$.

As expressed by the top managers, all such changes fulfilled patients' needs $(79.3 \%)$, and afterwards they satisfied the National Health Fund (Pol. NFZ, Narodowy Fundusz Zdrowia) $(65.5 \%)$ and staff $(58.6 \%)$. They stated that their staff is satisfied with changes under restructuration (48.3\%), while others answered 'I do not know' and 'No'. The respondents from the establishing entity declared that these changes took into consideration the needs of patients $(64.3 \%)$, followed by satisfied staff (50\%) and the National Health Fund (Pol. NFZ, Narodowy Fundusz Zdrowia) (42.9\%).

The top managers stated that the staff in their hospital was notified on planned restructuring operations and their implementation in the course of these changes (62.1\%). According to $72.4 \%$ of the hospital respondents, the staff was well disposed towards such implemented changes. The establishing entity representatives stated that their hospital staff was informed on 
planned restructuring operations and their implementation on an ongoing basis $(62.3 \%)$, and other people - during their implementation. $14.3 \%$ of the respondents did not know if the people employed at their hospital were well disposed towards changes, and $42.9 \%$ of them thought they were.

According to the hospital representatives, the staff area was most frequently indicated to be problematic during the implementation of restructuring operations $(76.9 \%$ based on 13 observations). The top managers of hospitals then considered resistance to changes as the cause of such problems (also 76.9\%), which led to delays in the baseline $(46.2 \%)$ and an extended duration of restructuring operations (30.8\%). Representatives of the establishing entity defined 5 areas of problems in the restructuring process; among them resistance of employed people and trade unions to changes (100\%) was most frequently indicated. Uncertainty about further employment (50\%), which led to staff strikes $(50 \%)$, was perceived as the cause of these problems.

In spite of restructuring operations, nearly $3 / 4$ of the hospital and establishing entity respondents thought that all the changes made were insufficient for the smooth operation of their hospitals. According to the top managers, further changes should focus on expanding their contract with the National Health Fund (Pol. NFZ, Narodowy Fundusz Zdrowia) (46.2\%), improving work organisation and acquiring extra financing for business operation ( $26.9 \%$ each). In turn, according to the establishing entity representatives, changes should then primarily focus on increasing work discipline (36.4\%), improving the conditions of patients' stay, further rationalisation of employment and remuneration (27.3\% each).

If it was possible to run restructuration again, the top managers would put more emphasis on involvement of their staff in the restructuring process $(38.9 \%)$, switching to flexible forms of employment $(27.8 \%)$ and an increase in the financial motivation of people accountable for restructuration $(11.1 \%)$. In their view, too little attention was paid to the smooth flow of information (50\%), delegation of responsibilities (43.8\%) and involvement of staff and trade unions into the restructuring planning (37.5\%). If the establishing entity respondents were to restructure their hospital again, they would pay more attention to convincing their staff of planned changes $(50 \%)$ and prepare detailed documentation on their implementation and impacts on individual hospital areas (35.7\%).

The top managers assessed cooperation with the establishing entity in the course of their hospital restructuration to be very good (48.3\%), whilst $13.8 \%$ chose the answer: "no support", and $27.65 \%$ of the respondents considered it to be at the right and appropriate level, whilst others - at a good lever. As the most common cause of dissatisfaction with their cooperation with the establishing entity, these respondents pointed to a lack of talks with trade unions $(66.7 \%)$ and no assistance in the processing of applications for financial assistance for the needed investments $(33.3 \%)$. The establishing entity respondents then assessed their cooperation with the hospital to be right and appropriate $(50 \%)$ - the last but one step in the four-step scale. Reluctance of people employed towards changes $(72 \%)$ was the most common cause of dissatisfaction with cooperation. 


\subsection{Assessment of restructuration of public hospitals and its effectiveness}

$89.7 \%$ of the hospital respondents defined the key objective of their restructuring activities. Most often they set just one objective (55.2\%). 34.5\% of the respondents identified two objectives. In the first place, the respondents specified improving the quality of provided services $(23.1 \%)$, then reduction of debts, operational balance, increase in revenues, reduction of hospital operating costs $(11.5 \%)$ to be their key objective. The top managers when specifying their key objectives - determined a percentage level of their achievement. Based on the feedback there was the average level of achievement for the first key objective calculated at $75.2 \%$, while the second goal - at $67.7 \%$.

Among the establishing entity respondents, 92.86\% said that there was a key objective defined in order to run restructuration. In this group, $53.85 \%$ pointed out to 1 objective, $23.08 \%$ - to 2 objectives, $15.38 \%$ - 3 objectives, and others - to more than 4 . The most frequently set objective was to reduce hospital debts (30\%), followed by improve hospital financial performance and liquidity, strengthen its position in the medical services market and rationalise investment projects, etc. (20\% each). Further key objectives were as follows: more efficient organisation of medical staff, more efficient occupation of hospital beds and use of clinic facilities, improvement of financial performance, efficient application of medical equipment, i.e. its relocation within hospitals $(10 \%$ each). The respondents - while giving their objectives of restructuring operations - also determined the percentage levels of their performance. Based on the feedback, the average achievement level of individual objectives was calculated, which amounted to $63.3 \%$ for the first objective and $56.0 \%$ for the second objective. Achievement of the key objective as defined by the hospital and the establishing entity, its degrees and causes of failure to reach $100 \%$ is shown in the table below.

Table 4.

Degree of achievement of the key objective

\begin{tabular}{|c|c|}
\hline Hospital & Establishing entity \\
\hline Main objectives - Objective 1 & Main objective - Objective 1 \\
\hline \multicolumn{2}{|c|}{ Average degree of achievement of the goal } \\
\hline $75.2 \%$ & $63.3 \%$ \\
\hline \multicolumn{2}{|c|}{ Maximum } \\
\hline $100 \%$ & $100 \%$ \\
\hline \multicolumn{2}{|c|}{ Minimum } \\
\hline $20 \%$ & $40 \%$ \\
\hline \multicolumn{2}{|c|}{ Cause for which the objective was not achieved at $100 \%$} \\
\hline High cost of hospital infrastructure maintenance & $\begin{array}{l}\text { No possibility to negotiate the contract with the } \\
\text { National Health Fund }\end{array}$ \\
\hline Objective progress - not finished & Resistance of trade unions to cost cutting \\
\hline No stable and long-term funding & Resistance of people employed \\
\hline Rapid development of medical technologies & Loss of credibility among hospital creditors \\
\hline $\begin{array}{l}\text { No approval of trade unions for regulatory changes and } \\
\text { deductions for the Company Social Fund }\end{array}$ & Compulsory payment orders \\
\hline Resistance of trade unions to cost cutting & $\begin{array}{l}\text { No sufficient money to purchase medical } \\
\text { equipment }\end{array}$ \\
\hline
\end{tabular}


Cont. table 4.

\begin{tabular}{|l|l|}
\hline $\begin{array}{l}\text { No tenders for new contracts ('old' contract terms are } \\
\text { valid for the next period) }\end{array}$ & $\begin{array}{l}\text { Failure to receive external funding from EU } \\
\text { programmes }\end{array}$ \\
\hline $\begin{array}{l}\text { No impact on the contract (its value) with the National } \\
\text { Health Fund }\end{array}$ & $\begin{array}{l}\text { Theft of disposable medical equipment in the } \\
\text { hospital }\end{array}$ \\
\hline Resistance of people employed & $\begin{array}{l}\text { Questioning the legitimacy of overwork conducted } \\
\text { by the hospital }\end{array}$ \\
\hline Rehabilitation programme in progress & $\begin{array}{l}\text { Reduction of the contract (its value) with the } \\
\text { National Health Fund }\end{array}$ \\
\hline Increased contracting requirements & $\begin{array}{l}\text { Regulatory changes - extra costs to adapt to their } \\
\text { requirements }\end{array}$ \\
\hline $\begin{array}{l}\text { No 'savings culture' among people employed in the } \\
\text { hospital }\end{array}$ & Social protests \\
\hline
\end{tabular}

Source: own research study based on the questionnaire results.

The hospital and establishing entity respondents were also asked to assess the success of all changes made in individual areas (expressed as a percentage). A breakdown of individual responses is shown below.

Table 5.

Success rates for changes made in particular restructuring areas

\begin{tabular}{|c|c|c|c|c|c|c|}
\hline & \multicolumn{3}{|c|}{$\begin{array}{r}\text { Hospital } \\
\end{array}$} & \multicolumn{3}{|c|}{ Establishing entity } \\
\hline Area of change & $\begin{array}{c}\text { Average success } \\
\text { rate }[\%]\end{array}$ & $\begin{array}{c}\text { Min. } \\
{[\%]}\end{array}$ & $\begin{array}{c}\text { Max. } \\
{[\%]}\end{array}$ & $\begin{array}{c}\text { Average success } \\
\text { rate }[\%]\end{array}$ & $\begin{array}{c}\text { Min. } \\
{[\%]}\end{array}$ & $\begin{array}{l}\text { Max. } \\
{[\%]}\end{array}$ \\
\hline services & 67.5 & 0.0 & 100.0 & 72.1 & 50.0 & 99.0 \\
\hline method of sales & 32.0 & 10.0 & 90.0 & 61.7 & 40.0 & 90.0 \\
\hline structure of hospital assets & 70.0 & 20.0 & 100.0 & 51.9 & 10.0 & 85.0 \\
\hline hospital employment & 69.5 & 30.0 & 100.0 & 61.3 & 10.0 & 99.0 \\
\hline technical area & 61.2 & 30.0 & 100.0 & 58.8 & 40.0 & 80.0 \\
\hline organisational & 72.7 & 40.0 & 100.0 & 58.8 & 30.0 & 95.0 \\
\hline management system & 80.6 & 30.0 & 100.0 & 77.0 & 40.0 & 99.0 \\
\hline hospital ownership structure & - & - & - & - & - & - \\
\hline capital structure & - & - & - & - & - & - \\
\hline debt structure & 82.8 & 40.0 & 100.0 & 67.8 & 40.0 & 90.0 \\
\hline
\end{tabular}

Source: own research study based on the questionnaire results.

According to the top managers, their undertaken restructuring operations were primarily related to the area of employment and organisation. The average success rate for changes made in these areas was calculated at $69.5 \%$ and $72.7 \%$. Changes provided by the establishing entity respondents most often referred to the area of organisation, where their average success rate was $58.5 \%$.

\subsection{Factors which negatively affect the effectiveness of restructuration}

As a result of the conducted questionnaire survey in the first two stages, there were 48 factors identified which negatively impacted the effectiveness of restructuring operations in public hospitals. Factors with their average assessment assigned by the experts at 60 or more were qualified for further research study; others were considered to be insignificant. The object relative relevance method was applied for the 30 factors selected in this manner. The aggregate ranks determined by this method were ordered in an ascending order. Due to the fact that the more significant impact an individual factor has on restructuring operations, the lower its rank, 
all the factors with their aggregate ranks over 353.5 were rejected. The ordered factors, along with their aggregate ranks, are shown in the table below.

Table 6.

Selected factors influencing the effectiveness of restructuration of public hospitals

\begin{tabular}{|l|c|}
\hline \multicolumn{1}{|c|}{ Factors } & $\begin{array}{c}\text { Aggregate } \\
\text { ranks }\end{array}$ \\
\hline $\begin{array}{l}\text { Incorrect formulation of the restructuring plan and its assumptions/no possibility to draw up } \\
\text { realistic financial forecasts due to the fact that it was impossible to estimate future revenues. }\end{array}$ & 170.5 \\
\hline Frequent changes in the positions of hospital directors. & 187.5 \\
\hline Reduction of a contract (its value) compared to the preceding year. & 190.5 \\
\hline Decision-making dependence between the hospital and the establishing entity. & 203.5 \\
\hline $\begin{array}{l}\text { Frequent regulatory changes making it necessary to incur financial resources for unplanned } \\
\text { investments to adapt to changes/requirements. }\end{array}$ & 239.5 \\
\hline No competence (knowledge and experience) to run restructuring operations in the hospital. & 246.5 \\
\hline No support for actions undertaken by the hospital on behalf of the establishing entity. & 256.5 \\
\hline $\begin{array}{l}\text { Failure to appoint a project team being accountable for the planning and implementation of } \\
\text { restructuring operations in the hospital. }\end{array}$ & 273.5 \\
\hline Failure to prepare pre-implementation/needs analyses. & 274.0 \\
\hline $\begin{array}{l}\text { Necessity to provide services beyond the limits specified in the contract with the National Health } \\
\text { Fund (Pol. NFZ, Narodowy Fundusz Zdrowia) due to the fact that it was unacceptable to refuse } \\
\text { patient hospitalisation. }\end{array}$ & 274.5 \\
\hline $\begin{array}{l}\text { No documentation on changes made under restructuring operations, including justification that } \\
\text { they are required to be conducted and their expected effects. }\end{array}$ & 283.5 \\
\hline
\end{tabular}

Source: own study.

The above-outlined factors which negatively impact the efficiency of restructuration can be divided into internal factors (i.e. those which can be factually impacted by the hospital), external factors (i.e. those which cannot be affected by the hospital) and mixed ones (i.e. those which can be partially impacted by the hospital). The most relevant internal failure factors of restructuration include: frequent changes at the positions of hospital directors, no competence (no knowledge and experience) to run restructuring operations in the hospital and failure to appoint a project team. The most important external factors are as follows: reduction of a contract (its value) compared to the preceding year, decision-making dependence between the hospital and the establishing entity (no autonomy in decision-making) and frequent regulatory changes which impose the need to implement changes in the hospital. As mixed factors, the following were identified: incorrect formulation of the restructuring plan and its assumptions/no possibility to draw up realistic financial forecasts, low credit rating at banks and no knowledge on the budget of planned restructuring operations.

\section{Conclusion}

In literature on the subject, there are a number of papers which refer to the key success factors of commercial enterprises improving their profitability or increase their competitiveness. There are relatively fewer papers on factors affecting the success of public 
entities, to which, in general terms, concepts such as profitability or competitiveness are not applied. An analysis of the health-care sector in the scope of hospitality shows, however, that competitiveness between public health-care providers exists (competing for contracts with the National Health Fund (Pol. NFZ, Narodowy Fundusz Zdrowia)). This is also the case with the issue of profitability (e.g. transformation of unprofitable hospitals generating debts which cannot be covered by them or their establishing entities). There is also no clear standing on the nomenclature of factors having an opposite effect compared to success factors. In reference to restructuring operations, they are often referred to by risk researchers and analysists as risk sources, barriers, failure factors or error makers.

The provided research results enrich the literature on the subject in several ways. They show how the planning process of restructuration in reference to public hospitals is run, then demonstrate all the areas covered by restructuration and operations undertaken in this areas and finally identify factors which adversely affect the restructuration of such entities. The research studies and their results lead one to state that there are no top-down guidelines for planning the restructuration of public hospitals, and thus each and every public hospital approaches the process in a different manner. Public hospitals in the Silesian Province (Śląskie Voivodeship) undertake restructuring operations in response to the need to recover their current standing in relation to an excessively high level of indebtedness. As a result, the most common set objectives referred to the area of financial issues (debt reduction, improved financial performance, etc.) and then to an increased competitive standing (strengthening their position in the medical service market, rationalisation of investment enterprises). All the actions undertaken in the course of restructuration focused on organisational, management and employment areas. The planned restructuration did not prove to be effective for all the hospitals. Under the conducted research studies, 30 factors which have a relevant negative impact on restructuration were identified. Among them there were factors over which a hospital may have direct (full) or limited influence or may have no influence at all. The most relevant factor is to adopt incorrect assumptions at the very beginning of planning activities on the restructuring plan with respect to financial forecasting.

\section{References}

1. Austen, A., Kotas, M. (2016). Wykorzystanie kluczowych czynników sukcesu w procesie zarządzania strategicznego w ośrodkach pomocy społecznej w Polsce - wyniki badań empirycznych. Journal of Management and Finance, 14(2/1), p. 46.

2. Dobska, D, \& Rogoziński, K. (2008). Podstawy zarządzania zakładem opieki zdrowotnej. Warszawa: PWN, p. 147-148. 
3. Filipek, A. (2016). Prakseologiczne aspekty jakości zarządzania kryzysowego. Zeszyty Naukowe Uniwersytetu Przyrodniczo-Humanistycznego w Siedlcach, Administracja i Zarzadzanie, 110, p. 41.

4. Furtak-Niczyporuk, M., \& Drop, B. (2013). Efektywność organizacji systemu państwowe ratownictwo medyczne. Studia Ekonomiczne, 168, p. 54.

5. Gierszewska, G., \& Romanowska, M. (2007). Analiza strategiczna przedsiębiorstwa, Warszawa: PWE, p. 169.

6. Hass-Symotiuk, M. (2011). System pomiaru i oceny dokonań szpitala. Warszawa: Wolter Kluwer business, p. 80.

7. Jeruzalski, T. (2009): Efektywność i skuteczność wdrażania systemów IT w administracji publicznej. Wspomaganie procesów podejmowania decyzji. Warszawa: CeDeWu, p. 6.

8. Kautsch, M., \& Lewandowski, R. (2013). Editorial. Obszary zarządzania w ochronie zdrowia. Przedsiębiorczość i Zarządzanie, XIV(10), p. 5.

9. Klich, J. (2013). Państwo i rynek w sektorze ochrony zdrowia w Polsce: kierunki i perspektywy. Studia Ekonomiczne, 139, p. 261.

10. Klich, J. (2013). Restrukturyzacja samodzielnych publicznych zakładów opieki zdrowotnej. Współczesne wyzwania, procedury i narzędzia. Warszawa: Wolters Kluwer business, p. 15.

11. Klonowska-Matynia, M., \& Stasiukiewicz, I. (2015). Analiza kluczowych czynników sukcesu jako metoda oceny pozycji spółki w sektorze. Zeszyty Naukowe Wydziału Nauk Ekonomicznych Politechniki Koszalińskiej, 19, p. 69.

12. Kotarbiński, T. (1982). Traktat o dobrej robocie. Wrocław: Zakład Narodowy im. Ossolińskich, p. 106.

13. Kotas, M. (2014). Kluczowe czynniki sukcesu ośrodków pomocy społecznej. Zeszyty Naukowe Politechniki Śląskiej, Organizacja i Zarzadzanie, 74, p. 362.

14. Kowal, W. (2013). Skuteczność i efektywność - zróżnicowane aspekty interpretacji. Organizacja i kierowanie, 4(157), p. 14.

15. Michalski, J. (2013). Czy system ochrony zdrowia może być efektywny? Studia Ekonomiczne, 168, p. 207.

16. Mozalewski, M. (2010). Rodzaje i metody restrukturyzacji przedsiębiorstw. Ruch Prawniczy, Ekonomiczny i Socjologiczny, 2, p. 233.

17. Nalepka, A. (1998). Zarys problematyki restrukturyzacji przedsiębiorstw. Kraków: Antykwa, 40.

18. Nieżurawski, L., \& Nieżurawska, J. (2013). Wybrane przyczyny sukcesu i porażek internacjonalizacji przedsiębiorstw. Zarządzanie i Finanse, 11(4/2), p. 274.

19. Pasieczny, J. (2013). Ryzyko w procesach restrukturyzacji. Zarządzanie i Finanse, 11(4/3), p. 357.

20. Penc, J. (2003). Menedżer w działaniu. Sekrety prowadzenia biznesu. Warszawa: C.H. Beck, p. 16. 
21. Pszczołowski, T. (1978). Mała encyklopedia prakseologii i teorii organizacji. Wrocław: Zakład Narodowy im. Ossolińskich, p. 60.

22. Pyszka, A. (2015). Istota efektywności. Definicje i wymiary. Zeszyty Naukowe Uniwersytetu Ekonomicznego w Katowicach, 230, p. 15.

23. Ropęga, J. (2016). Czynniki niepowodzeń gospodarczych małych przedsiębiorstw w aspekcie nowego paradygmatu cywilizacyjnego. Prace Naukowe Uniwersytetu Ekonomicznego we Wrocławiu, 450, p. 502.

24. Saryusz-Wolska, H., \& Wronka, M. (2013). Efektywność w opiece zdrowotnej - zarys wielowymiarowego problemu w okresie transformacji. Studia Ekonomiczne, Zeszyty Naukowe, Wydziałowe Uniwersytetu Ekonomicznego w Katowicach, 256, p. 258.

25. Skrzypek, E. (2012). Efektywność ekonomiczna jako ważny czynnik sukcesu organizacji. Prace Naukowe Uniwersytetu Ekonomicznego we Wrocławiu, 262, p. 315.

26. Sułkowski, M., \& Wolniak, R. (2013). Przegląd stosowanych metod oceny skuteczności i efektywności organizacji zorientowanych na ciągłe doskonalenie. Zeszyty Naukowe Politechniki Ślaskiej, Organizacja i Zarzadzanie, 67(1 900), p. 65.

27. Suszyński, C. (1999). Restrukturyzacja przedsiębiorstw. Proces zarzadzania zmianami. Warszawa: PWE, p. 124.

28. Wronka, M. (2017). Kluczowe czynniki sukcesu przedsiębiorstw ekonomii społecznej. Ślaska ekonomia społeczna, 4. http://rops-katowice.pl/dopobrania/2013.11.26_wronka_ art.pdf.

29. Zakrzewska-Bielawska, A. (2004). Ograniczenia procesu restrukturyzacji polskich przedsiębiorstw. Zeszyty Naukowe Politechniki Łódzkiej, Organizacja i Zarządzanie, 39, p. 7.

30. Zakrzewska-Bielawska, A. (2007). Czynniki sukcesu dużych polskich firm produkcyjnych. Prace i Materiały Wydziału Zarządzania Uniwersytetu Gdańskiego, Sukces organizacji. Uwarunkowania wewnętrzne i zewnętrzne, p. 276-277. 